\title{
Prognosis of Misgav-Ladach Caesarean Sections in an African Environment: Case of the Banfora Regional Hospital in Burkina Faso about 110 Cases
}

\author{
Ouattara Adama1, Yaméogo Relwendé Barnabé1, Kaboré Francois Xavier Gueswendé1, \\ Kiemtoré Sibraogo1, Kain Dantola Paul', Sawadogo Yobi Alexi', Dao Yissou², \\ Ouedraogo Issa ${ }^{3}$, Ouédraogo Charlemagne Marie', Ouédraogo Ali1, \\ Millogo/Traoré Francoise ${ }^{1}$, Thieba/Bonané Blandine ${ }^{1}$
}

\footnotetext{
${ }^{1}$ The University Teaching Hospital of Ouagadougou, Ouagadougou, Burkina Faso

${ }^{2}$ The Regional Hospital of Banfora, Banfora, Burkina Faso

${ }^{3}$ The Regional Hospital of Ouahigouya, Ouahigouya, Burkina Faso

Email: ouattzangaadama@yahoo.fr
}

How to cite this paper: Adama, O., Barnabé, Y.R., Gueswendé, K.F.X., Sibraogo, K., Paul, K.D., Alexi, S.Y., Yissou, D., Issa, O., Marie, O.C., Ali, O., Francoise, M. and Blandine, T. (2017) Prognosis of Misgaw Ladach Caesarean Sections in an African Environment: Case of the Banfora Regional Hospital in Burkina Faso about 110 Cases. Open Journal of Obstetrics and Gynecolo$g y, 7,1006-1015$.

https://doi.org/10.4236/ojog.2017.79101

Received: August 20, 2017

Accepted: September 25, 2017

Published: September 28, 2017

Copyright $\odot 2017$ by authors and Scientific Research Publishing Inc. This work is licensed under the Creative Commons Attribution International License (CC BY 4.0).

http://creativecommons.org/licenses/by/4.0/ (c) (i) Open Access

\begin{abstract}
Objective: To analyze the caesarean section prognosis aspects according to Misgav-Ladach versus classical technique in the regional hospital of Banfora. Materials and Methods: This is about a randomized clinical test of 2 groups carried in the regional hospital in Banfora on a two-month period from 1st October to 30 November 2015. In the first group, 66 patients had benefited from a caesarean section by the Misgav-Ladach technique. In the control group, 44 patients had benefited from a caesarean in the conventional technique. Were included in our sample all patients having benefited from a cesarean in the study site during the study period and who had consented to participate in the study. All patients were followed until the postpartum healing of the surgical wound. All prognostic elements have been compared. The results were analyzed with Epi Info 3.5.1 software and the significance level was set at 5\%. Results: The indications for cesarean section were dominated by maternal causes in 70 cases (63.6\%). The average duration of the surgical procedure was $27.98 \mathrm{~mm}$ for Misgav-Ladach technique versus $28.27 \mathrm{~mm}$ for the conventional technique $(\mathrm{p}=0.49)$. The evaluation of blood loss by the change in hemoglobin pre- and post-operative did not find statistically significant differences between the two techniques $(p=0.6)$. The evaluation of the number of intraoperative suture used, was in favor of the technique of Misgav-Ladach $(\mathrm{p}=0.007)$. The evolutionary trend in the intensity of postopera-
\end{abstract}


tive pain was in favor of the technique of Misgav-Ladach. The average time of wound healing was 16.33 days for group 1 versus 21,27 days for group $2(\mathrm{p}=$ 0.0001 ). Postoperative morbidity was greater with the conventional technique in comparison to Misgav-Ladach's ( $p=0.046)$. There was no statistically significant differences in length of hospital stay $(\mathrm{p}=0.056)$. Conclusion: The Misgav-Ladach cesarean section reduces operative risk. The adoption and diffusion of this technique to the national level and its effective integration into training curriculas should contribute to reducing maternal morbidity and mortality of abdominal delivery.

\section{Keywords}

Cesarean, Misgav-Ladach, Morbidity, Banfora

\section{Introduction}

In Burkina Faso, maternal mortality is high. It was estimated in 2010 to 341 per 100,000 live births [1]. Among the multifactorial causes of maternal mortality, there was a deficiency in covering the supply of obstetric and neonatal emergency care and cesarean section is an essential component [2] [3].

Cesarean section consisting of artificial birth surgically opening the pregnant uterus [4]; involves significant risks if it is not controlled [5]-[11]. In order to reduce maternal and fetal risks associated with this procedure, Mr. STARK has developed a simplified technique called "Caesarean of Misgav-Ladach" [10] [12].

In Africa comparative studies between conventional technique (CC) known and the Misgav-Ladach's (MLC) have already been made by colleagues in the region confirming the interest of the extension of the Misgav-Ladach-technique because of reduced financial cost and simplicity in surgical procedure with fewer maternal and fetal complications [13] [14] [15] [16]. But it should be noted that the socio-cultural, economic and environmental context of these countries differ from that of Burkina Faso and an extrapolation of the results of these studies would not be possible at first sight.

Also through this study the authors propose to analyze comparatively prognostic aspects of the technique of Misgav-Ladach versus conventional technique in a referral hospital with large carrying capacity in an urban area that to say the regional hospital of Banfora.

\section{Materials and Methods}

\subsection{Type of Survey and Sampling}

It came from a randomized clinical test with two arms which took place over two months from 1st September to 30 October 2015. The obstetrics and gynecology department of the regional hospital of Banfora served us as framework study. This department employs 2obstetricians' doctors, 28 midwives, 10 nursesspecialized in anesthetists, 13 nurses specialized in surgery. The regional hospital cov- 
erage area includes an urban area and a rural part for a total population of about $1,200,000$ persons.

Were included in our study all patients who underwent a caesarean on a pregnancy age greater than 28 weeks gestation, during the study period. Were excluded from our sample, cesareans for eclampsia, sickle cell SS, SC, fetal death, lost sight of patients, as well as those in which consent was not obtained. After consent, the randomization was to simple random sampling without replacement of the study group in the ratio of $2 / 3$ in favor of Misgav-Ladach's technique.

\subsection{Data Collection and Analysis}

We used an individual record of data collection informing on epidemiological, clinical, therapeutic and prognostic of patients. The admission records, clinical records, prenatal consultation booklets, the operative report records, anesthesia records resuscitation, records bandages and postoperative follow-up were also exploited. The data were entered into computer and analyzed using EpiData and SPSS. Data collected in intraoperative and postoperative in both groups were compared. Statistical tests of Student and Khi2 were used to compare the respective average and proportions. The significance level adopted was 5\%.

\subsection{Evaluation and Management of Postoperative Pain}

The visual analog scale (VAS) was the reference tool. Pain considered low for VAS lower to 3 did not receive support. The one considered moderate by a VAS between 3 and 6 was supported by analgesics level 1, orally. The one considered strong by VAS greater than 6 were supported by painkillers level 2, parenterally.

\subsection{Assessment of Blood Loss}

The blood loss was indirectly assessed by the calculated difference in hemoglobin between the before and after cesarean 24 hours. This change in hemoglobin was an indirect assessment of blood loss.

\subsection{Antibiotic}

All patients benefited from bolus antibiotic, ceftriaxone during the cesarean and with amoxicillin after the cesarean.

\section{Results}

\subsection{Epidemiological Aspects}

\subsubsection{Frequency}

During the study period, 532 births were registered including 157 caesarean sections (29.51\%). Among these patients 30 were lost during postoperative care and 17 were excluded for eclamptic syndrome, sickle cell and fetal intrauterine death. The sample was then composed of 110 patients or $70.06 \%$ of all caesarean sections. 


\subsubsection{Profile of Patients}

The average age was 27.24 years (16 - 44). The age groups 15 - 20 years and 20 25 years accounted for $79.09 \%$ of women who had a caesarean.

The average number of childbirth was $2.12(1-7)$. Those having 3 to 5 childbirth were the most represented with $48.18 \%$ of cases.

In our sample, $66.36 \%$ of patients had no economic activity.

\subsection{Caesarean Indications}

\subsubsection{Fetal Indications}

The distribution of patients according fetal indications of the cesarean has been shown in Table 1.

\subsubsection{Maternal Indications}

The distribution of patients according to maternal indications of cesarean was represented in Table 2.

\subsection{Prognostic Aspects}

\subsubsection{Caesarean Timing}

The average duration of the conventional technique was 28.27 minutes (20 - 58). That of Misgav-Ladach was 27.98 minutes (15 - 48). Furthermore $61.36 \%$ of the conventional technique have a duration less than $34 \mathrm{~min}$ and $78.79 \%$ of Misgav-Ladach have a duration less than $34 \mathrm{~min}(\mathrm{p}=0.49)$.

\subsubsection{Blood Loss}

During the study period, only 02 patients or $1.8 \%$ of the patients received a blood transfusion during surgery. The distribution of patients according to the change in hemoglobin was presented in Table 3.

\subsubsection{Number Suture Threads}

The number of suture threads used during the intervention by type of cesarean section was presented in Table 4.

\subsubsection{Type of Anesthesia}

In our study 8 patients or $7.27 \%$ have benefited from a general anesthesia, 97 or $88.18 \%$ have received regional anesthesia. A regional anesthesia secondarily

Table 1. Distribution of patients according to fetal mandatory information.

\begin{tabular}{lcc}
\hline \multirow{2}{*}{ Fetal Indications } & Number & Pourcentage \\
\cline { 2 - 3 } & $(\mathrm{n})$ & $(\%)$ \\
\hline dystocic presentation & 21 & 19.1 \\
$-\quad$ breech & 15 & 13.64 \\
$-\quad$ Transverse & 4 & 3.64 \\
- Face/Forehead & 2 & 1.82 \\
Macrosomia & 15 & 13.64 \\
Funicular abnormality & 4 & 3.64 \\
Total & 40 & 36.4 \\
\hline
\end{tabular}


Table 2. Distribution of patients according to maternal indications.

\begin{tabular}{|c|c|c|}
\hline \multirow{2}{*}{ Maternal indications } & Number & Pourcentage \\
\hline & (n) & (\%) \\
\hline Obstructed labor & 32 & 29.1 \\
\hline - Basin generally narrowed & 20 & 18.18 \\
\hline - Asymmetrical basin & 5 & 4.55 \\
\hline - Immature basin & 1 & 0.91 \\
\hline - Immature Basin & 1 & 0.91 \\
\hline - rectovaginal fistula & 1 & 0.91 \\
\hline - Myomasprevia & 3 & 2.73 \\
\hline - renal tumor & 1 & 0.91 \\
\hline Dynamic dystocia & 19 & 17.27 \\
\hline - $\quad$ start dystocia & 11 & 10 \\
\hline - hyperkinesia & 5 & 4.55 \\
\hline - hypokinesia & 3 & 2.72 \\
\hline soft tissue dystocia & 15 & 13.64 \\
\hline - Anomaly of expulsion period & 6 & 5.46 \\
\hline - expansion stop & 9 & 8.18 \\
\hline Bleeding & 4 & 3.64 \\
\hline - Retro-placental hematoma & 2 & 1.82 \\
\hline - previa placenta & 2 & 1.82 \\
\hline Total & 70 & 63.6 \\
\hline
\end{tabular}

Table 3. Changes in hemoglobin depending on the type of caesarean.

\begin{tabular}{cccccc}
\hline \multirow{2}{*}{$\begin{array}{c}\text { Changes in } \\
\text { Hemoglobin }(\mathrm{g} / \mathrm{dl})\end{array}$} & \multicolumn{5}{c}{ Type of Caesarean } \\
\cline { 2 - 5 } & (n) & CC & (n) & $\%$ \\
\cline { 2 - 5 } & 29 & 65.91 & 49 & 75 \\
\hline to 2 & 13 & 29.55 & 15 & 23.44 \\
2.1 to 4 & 2 & 4.54 & 1 & 1.56 \\
4.1 to 6 & 44 & 100 & 64 & 100 \\
\hline Total & & & & \\
\hline
\end{tabular}

$\mathrm{P}=0.6$

Table 4. Distribution of the patients according to the number of suturesand the type of ceasarean.

\begin{tabular}{cccccc}
\hline \multirow{2}{*}{ Number of suture used } & \multicolumn{5}{c}{ Type of ceasarean } \\
\cline { 2 - 6 } & (n) & $\%$ & (n) & $\%$ \\
\cline { 2 - 5 } & 19 & 43.18 & 49 & 74.24 \\
\hline 2 sutures & 21 & 47.72 & 16 & 24.24 \\
3 sutures & 4 & 10.1 & 1 & 1.52 \\
4 sutures and more & $\mathbf{4 4}$ & 100 & 66 & 100 \\
Total & & & &
\end{tabular}

Khi-deux de Pearson: 12.112; DDL: 3; P: 0.007. 
converted into general anesthesia was performed into 5 patients or $4.54 \%$.

\subsubsection{Control of Post-Operative Pain}

The evolution of the control of postoperative pain using the technique was shown in Figure 1.

\subsubsection{Healing of the Surgical Wound}

The distribution of patients according to the period of the healing of the wound has been presented in Table 5 .

\subsubsection{Postoperative Morbidity}

The distribution of patients according to postoperative morbidity was presented in Table 6.

\subsubsection{Hospitalization Stay}

The mean hospital stay was 2.75 for the conventional technique against 2.27 days for Misgav-Ladach's ( $\mathrm{p}=0.056)$.

\section{Discussion}

\subsection{Caesarean Section Timing}

In our series, we found an average timing of 28.27 minutes for the conventional technique and 27.98 minutes for Misgav-Ladach's with a non-significant p-value

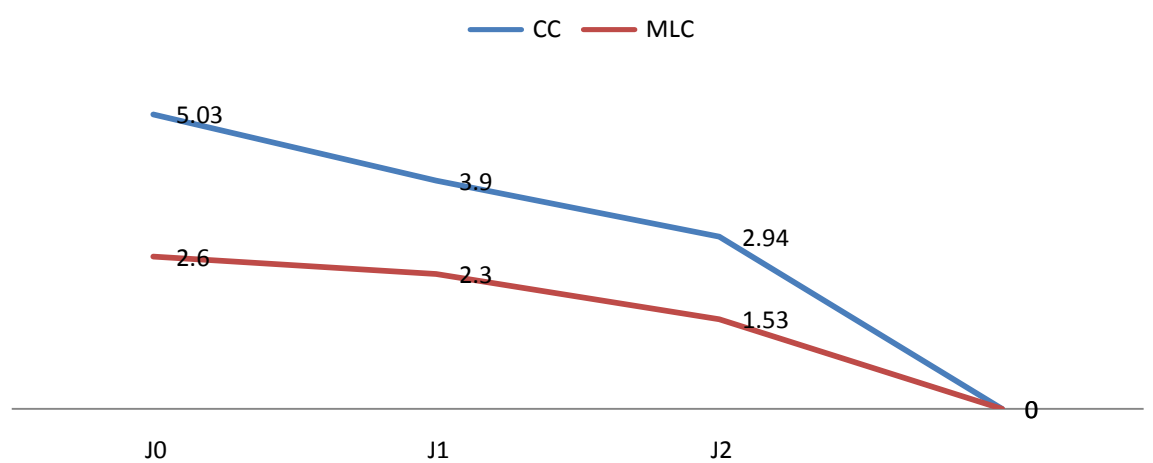

Figure 1. Evolution of the post operative pain in time according to the technique used.

Table 5. Distribution of patients according to healing time and the type of caesarean.

\begin{tabular}{ccccc}
\hline & \multicolumn{4}{c}{ Type of caesarean } \\
\cline { 2 - 5 } Healing time (days) & \multicolumn{3}{c}{ CC } & MLC \\
\cline { 2 - 4 } & (n) & $\%$ & 31 & $\%$ \\
\hline $7-14$ & 11 & 25 & 26 & 39.97 \\
$15-21$ & 13 & 29.54 & 8 & 12.12 \\
$22-29$ & 13 & 29.54 & 1 & 1.51 \\
30 and more & 7 & 15.91 & 66 & $100 \%$ \\
Total & 44 & $100 \%$ & & \\
\hline
\end{tabular}

$\mathrm{p}=0.001$ 
Table 6. Distribution of patients according to the postoperative morbidity and the technique.

\begin{tabular}{lccc}
\hline Morbidity & CC & MLC & p \\
\hline Parietal suppuration & & & $\mathrm{p}=0.046$ \\
- no & $36(81.36)$ & $62(93.94)$ & \\
- yes & $8(18.18)$ & $4(6.06)$ & \\
Postoperative anemia & & & $\mathrm{p}=0.167$ \\
- non & $25(56.82)$ & $46(69.7)$ & \\
- oui & $19(43.18)$ & $20(30.3)$ & \\
\hline
\end{tabular}

of 0.49. We cannot conclude that the practice of Misgav-Ladach is faster than the conventional. This could be explained by the fact that most young practitioners do not respect more rigorously all the time described for conventional, the closing time of the parietal and visceral peritoneum were dropped. The influence of the non-closure of the visceral peritoneum on operative time was analyzed by Nagele [17]. From a randomized study it showed that the non-closure of the peritoneum allows a considerable reduction in operative time (56.9 minutes versus 50.6 minutes with $\mathrm{p}<0.001)$.

The average duration of Misgav-Ladach in our series is lower than that reported by Moreira, 36 minutes [16] and greater than that of $20.4 \mathrm{~mm}$ reported respectively by Studzinski [18] and Ansaloni [19]. The differences noted between the series could be explained by the number of years of practical experience. Several studies comparing the Misgav-Ladach and the conventional have found a reduction in the operating time with Misgav-Ladach [13] [15] [18] [19] [20] [21]. Reducing the chirurgical intervention times described in Misgav-Ladach may be explained by several factors [18] [19] [21]:

- the speed of the incision of Joel Cohen,

- the non-separation of segmental pre peritoneum allows uterus faster opening,

- non closure of visceral peritoneum and the parietal peritoneum,

- closure of the fascia with a running suture,

- skin closure without reconciliation subcutaneous tissue with only 4 to 5 points of Blair Donati.

During the conventional caesarean 6 tissue layers are closed while in the cesarean of Misgav-Ladach only three layers are sutured (Uterus, fascia, skin), so explaining the timeliness of this latest.

\subsection{Blood Loss}

In our series, we found a mean change in hemoglobin concentration of $1.69 \mathrm{~g} / \mathrm{dl}$ for the conventional versus $1.37 \mathrm{~g} / \mathrm{dl}$ for Misgav-Ladach with a value of $\mathrm{p}=0.6$ insignificant. Our series using an indirect assessment reports no difference in blood loss using the technique. Other authors like Dar J [22] and Studzinski [18] 
by direct quantification of blood loss, showed that the Misgav-Ladach is less bleeding than the conventional. This difference in blood loss between the two techniques, could be explained by the fact that in the Misgav-Ladach's different layers of the wall are stretched and not severed and that the vessels are not harmed reducing the risk of major bleeding.

\subsection{Number of Threads of Suture}

In our series, the average number of threads of suture used was 2.84 and 2.27 for $\mathrm{CC}$ for MLC with a value of $\mathrm{P}=0.007$, significant. We can conclude that the MLC uses less thread than the CC. Our results are similar to those of Koné A [14] reported a mean number of 2.5 and Moreira [16] which reported a number of 2.92. The gain of thread with MLC may be explained by the difference in the number of layers to be sutured in both types of cesarean (CC: 6 ; MLC: 3 ).

\subsection{Healing Time}

In our series the mean healing time was 16.33 days to 21.97 days for MLC versus the CC with a value of $\mathrm{p}=0.001$, significant. The healing time of the MLC is shorter than that of the CC. This is easily understood since the MLC, one avoids tearing the tissue, the spacing being the golden rule.

\subsection{Postoperative Parietal Suppuration}

In our series, we recorded a suppurating rates in parietal CC18.18\% against $6.06 \%$ in MLC with a value of $\mathrm{p}=0.046$, significant. The CC is a more provider of suppuration than the MLC. This difference can be explained by the type of suture. Extra-running sutures dermal and intradermal are source of inflammatory response by their presences in situ until it they are resolved.

\section{Hospitalization Stay}

In our series the mean hospitalization stay of patients was 2.75 for the CCL against 2.27 days for CML with a value of $\mathrm{p}=0.056$, not significant. We cannot say that the CML shortens hospitalization time. Similarly, Moreira [16] in his series reported no significant difference ( 7.92 days to 8.05 days).

However it should be noted that the average length of hospitalization in our series is better than 5.2 days reported by Sawadogo Burkina Faso, those 9.3 days and 11 days respectively reported by Tégueté in Bamako [23] and Annie in Cotonou [24]. This short stay of our patients could be explained by head of department's decision to ensure early lifting of patients by allowing them to come out the second or third day in the absence of maternal complications.

\section{Conclusion}

Caesarean section by Misgav-Ladach is a reliable technique, it is fast and simple. This technique eliminates unnecessary time of surgery and limits the risk complications. It is nowadays an interesting alternative in the practice of emergency 
caesarean under-medicalized and low-income countries. Its dissemination at national level will let us benefit from secure delivery in our context of poverty.

\section{References}

[1] Ministry of Economy and Finance (2012) Survey of Demography and Health. INSD, Ouagadougou, 92.

[2] Ouedraogo, C., Testa, J., Sondo, B. and Kone, B. (2001) Analysis of Risk Factors for Severe Maternal Morbidity in Ouagadougou, Burkina Faso. Application to the Antenatal Record. Black African Medicine, 1, 403-410.

[3] World Health Organization (WHO) (2010) Maternal Mortality Is Falling. Science and Health: September 15, 2010. World Health Organization, Geneva.

[4] Meddounm, C.R. (2001) Caesarean. Encyclopedia Medico-Surgical, Surgical Technique-Gynecology, 1, 20.

[5] Allen, V.M., O'connell, C.M., Liston, R.M. and Baskett, T.F. (2003) Maternal Morbidity Associated with Caesarean Delivery without Labor Compared with Spontaneous Onset of Labor at Term. Obstetrics \& Gynecology, 102, 477-482.

[6] Burrows, L.J., Meyn, T.H.E. and Weber, A.M. (2004) Maternal Morbidity Associated with Vaginal versus Cesarean Delivery. Obstetrics \& Gynecology, 103, 907-912. https://doi.org/10.1097/01.AOG.0000124568.71597.ce

[7] Fenton, P.M., Whitty, C.J. and Reynolds, F. (2003) Caesarean Section in Malawi: Prospective Study of Early Maternal and Perinatal Mortality. The BMJ, 327, 587-590. https://doi.org/10.1136/bmj.327.7415.587

[8] Hager, R.M., Daltveitak, Hofoss, D., Nilsen, S.T, Kolaas, T., Oian, P. and Henriksen, T. (2004) Complications of Cesarean Deliveries: Rates and Risk Factors. American Journal of Obstetrics \& Gynecology, 190, 428-434. https://doi.org/10.1016/j.ajog.2003.08.037

[9] Hall, M.H. and Bewley, S. (2002) Maternal Mortality and Fashion Delivery. Lancet, 354, 776-777. https://doi.org/10.1016/S0140-6736(05)76016-5

[10] Stark, M.A. (2004) Technical of Cesarean Section: The Misgav-Ladach Method. In: Popkin, D.R. and Peddle, L.J., Eds., Women's Health Today. One Current Research and Clinical Practice Perspectives. Parthenon Publishing Group, New York, 81-85.

[11] Subtle, D, Vaast, P., Dufour, P., Depret, M. and Codaccioni, X.F. (2000) Consequences PUECH Mother of Cesarean Section Compared with Vaginal Delivery. Journal De Gynecologie, Obstetrique Et Biologie De La Reproduction, 29, 10-16.

[12] Holmgreng, G., Sjöholm, L. and Starkm, M. (2009) The Misgav Ladach Method for Cesarean Section: Method Description. Acta Obstetricia et Gynecologica Scandinavica, 78, 615-621. https://doi.org/10.1034/j.1600-0412.1999.780709.x

[13] Kazadi, J., Tine, C. and Diene, P.C. (2001) Interest Caesarean-Misgav Ladach in the Management of Dystocia in the Gynecology Department Obstetrics St. John of God, Thies, Senegal. Black African Medicine, 48, 7.

[14] Kone, A.M. (2004-2005) Comparative Study of Classical Cesarean and Cesarean-Misgav Ladach, Bamako, Mali. Ph.D. Thesis, No. 62, Mali.

[15] Lansac, J., Body, G. and Magnin, G. (2008) Surgical Practice Obstetric Gynaecology. Masson, Paris, 111-125.

[16] Moreira, P., Moreau, J.C., Mefaye, S.K., Faye, E.O. and Diadhiou, F. (2000) Cesarean Classical Caesarean Sections "Misgav Ladach". Obstetrical and Gynecological Clinic, CHU Le Dantec, Ar Pasteur, Dakar. 
[17] Nagele, F., Karash, H., Spitzer, D., Staudach, A., Karaseghs, S., Beck, A. and Hussein, P. (2006) Closure or Non Closure of the Peritoneum at Cesarean Vesceral Delivery. American Journal of Obstetrics \& Gynecology, 174, 1366-1370. https://doi.org/10.1016/S0002-9378(96)70686-5

[18] Studzinski, Z. (2002) Caesarean Method Misgav Ladach Compared with Pfannenstiel Technique in Slupsk Regional Hospital in Poland. Ginekologia Polska, 73, 672-676.

[19] Ansaloni, L., Brundisini, R., Moninog, G. and Kiura, A. (2001) Prospective, Comparative and Randomized Technique Misgav Ladach to That of Traditional Cesarean of Kenya Nazareth Hospital. World Surgery, 9, 1164-1172. https://doi.org/10.1007/BF03215866

[20] Jamet, F., Benos, P., Hedon, B. and Laffargue, F. (2006) Caesarean Section in a Precarious Situation. Revue Française de Gynécologie et d'Obstétrique, 91, 486-492.

[21] Popiela, A., Panszczyk, M., Korzeniew, J. and Baranowski, W. (2000) Clinical Comparative Analyse Caesarean Misgav Ladach and by Caesarean Pfannenstiel. Ginekologia Polska, 71, 255-257.

[22] Darj, E. and Nordstrom, M.L. (2009) The Misgav Ladach Method for Cesarean Section Compared to the Pfannenstiel Method. Acta Obstetricia Et Gynecologica Scandinavica, 78, 37-41. https://doi.org/10.1080/j.1600-0412.1999.780109.x

[23] Tégueté, I. (2006) Clinical Study and Epidemiological Caesarean Section at the National Maternity Hospital Point G from 1991 to 1993 (about a Case Control Study of 1544 Cases). Ph.D. Thesis, Bamako (Mali), No. 17.

[24] Selome Annie, F. (2001) Operation Caesarean Section at the Maternity Lagoon Cotonou. A Retrospective Study from 1995 to 1995 and Prospectively from April to June 2000 to about 5702 Cases. Ph.D. Thesis, Bamako (Mali), No. 53.

\section{Submit or recommend next manuscript to SCIRP and we will provide best service for you:}

Accepting pre-submission inquiries through Email, Facebook, LinkedIn, Twitter, etc. A wide selection of journals (inclusive of 9 subjects, more than 200 journals)

Providing 24-hour high-quality service

User-friendly online submission system

Fair and swift peer-review system

Efficient typesetting and proofreading procedure

Display of the result of downloads and visits, as well as the number of cited articles

Maximum dissemination of your research work

Submit your manuscript at: http://papersubmission.scirp.org/

Or contact ojog@scirp.org 